\title{
Effects of Lexicality and Regularity on Reading Aloud Performance in Aphasia
}

\author{
Woon Jeong Kim, Jee Eun Sung \\ Department of Communication Disorders, Graduate School, Ewha Womans University, Seoul, Korea
}

\author{
Correspondence: Jee Eun Sung, PhD \\ Department of Communication Disorders, \\ Ewha Womans University, 52 Ewhayeodae-gil, \\ Seodamun-gu, Seoul 03760, Korea \\ Tel: $+82-2-3277-2208$ \\ Fax: +82-2-3277-2122 \\ E-mail: jeesung@ewha.ac.kr
}

Received: January 5, 2017

Revised: February 9, 2017

Accepted: February 19, 2017

This work was supported by the Ministry of Education of the Republic of Korea and the National Research Foundation of Korea (NRF2016S1A5B6913884).

\begin{abstract}
Objectives: The purpose of the study was to evaluate the reading ability of persons with aphasia (PWA) according to lexicality and regularity. Methods: Twenty individuals with aphasia and 20 age- and education-matched normal individuals participated in the study. Experimental stimuli were manipulated based on the lexicality and regularity of two-syllable structures at word-level. Accuracy (\%) served as a dependent measure, and the types of error were analyzed. Results: For the reading accuracy, PWA performed significantly worse than the control group. Participants demonstrated greater difficulties in reading non-words and irregular words across the groups. The two-way interaction between group and lexicality was significant, indicating that PWA demonstrated greater difficulties in reading non-words than words compared to the control group. Regression analyses revealed that regular non-word condition accounted for $47.7 \%$ of the total variance as a significant predictor. In the error type analyses, the error ratio of regular non-word condition was $71.74 \%$, which was greater than that of word condition, $28.26 \%$. Regularization error was $14.75 \%$ in non-word condition and $9.36 \%$ in word condition. Conclusion: These results indicated that PWA demonstrated greater reading difficulties than the control group, and their performance was differentially affected by the lexicality. Lexicality seems to play a critical factor in differentiating PWA from the normal control group. The results are consistent with previous findings that suggested that non-word reading was more difficult than words. The current study suggested that overall severity of aphasia was predicted by regular non-word condition, which placed greater processing burden on grapheme-to-phoneme conversion.
\end{abstract}

Keywords: Aphasia, Reading, Lexicality, Regularity
실어증은 뇌손상으로 인한 후천적인 언어장애로, 실어증 환자의 언어결함은 말하기, 듣기, 읽기, 쓰기 등 모든 언어영역에서 나타날 수 있다(McNeil \& Pratt, 2001). 실어증 환자의 대부분은 읽기 능력 에서 결함을 보이며(Patterson \& Marcel, 1977; Rosenbek, LaPointe, \& Wertz, 1989), 이러한 읽기 결함은 범위와 중증도가 다양하다 (Knollman-Porter, Wallace, Hux, Brown, \& Long, 2015).

실어증 환자의 구어 능력이 임상 현장에서 우선적으로 다루어지 며, 읽기 결함은 이차적인 관심사로 여겨진다(Conklyn, Novak, Boissy, Bethoux, \& Chemali, 2012; Lynch, Damico, Abendroth, \& Nelson, 2013). 그러나 읽기 결함은 개인의 모든 생활에 큰 영향을
미친다(Webster et al., 2013). 또한 실어증 환자의 읽기 결함이 다양 한 일상 활동 참여에 영향을 미치는 만성 상태로 대부분 남아있으 며(Holland, 2007; Parr, 1995), 읽기 능력의 회복이 삶의 질 및 기능 의 회복에 중요한 역할을 하기 때문에 보다 관심을 가질 필요가 있 다(Obregon, 2008; Strauss, 1999).

읽기 능력의 평가는 읽기(reading aloud)와 읽기 이해(reading comprehension)로 구분되고(Sanders, 2001), 자극의 길이 및 문법 적 복잡성에 따라 철자, 음절, 단어, 구/문장, 문단으로 나뉜다(Kim, 2012). 이 중 읽기는 철자 자극의 처리와 언어 산출 메커니즘의 사 용을 모두 포함하는 과정으로(Silverberg, Vigliocco, Insalaco, \& 
Garrett, 1998), 평가를 통해 주어진 문자 자극의 시각적, 음운적, 의 미적 처리뿐만 아니라 말소리의 산출까지 다양한 영역에 접근할 수 있다. 또한 단어는 문장 내에서 의미를 가지는 기본 단위이므로, 전 반적인 언어 처리를 위해서는 단어의 처리가 우선적으로 이루어져 야한다(Kim, Lee, \& Jung, 2009).

한글 읽기에 가장 적합한 읽기 모형으로 Coltheart (1978)가 제안 한 이중경로모형(dual route model)이 제기되고 있다(Yi, 1996; Cho, Jung, \& Nam, 2002; Cho, 2005; Tae, Lee, \& Lee, 2015). 이중경로모 형은 문자 자극의 처리가 구분되면서도 상호작용하는 두 경로에 의해 이루어진다고 설명한다(Coltheart, 1978; Coltheart, Curtis, Atkins, \& Haller, 1993; Humphreys \& Evett, 1985). 하나는 어휘 경 로 또는 직접 경로로, 제시된 자극을 시각적으로 탐색하여 글자로 인지하고, 해당 철자를 철자어휘집에서 찾아 심성어휘집에서 의미 정보를 활성화시킨다. 이러한 철자 및 의미정보를 활용하여 해당하 는 발음정보를 인출하여 읽는 것이다. 또 하나는 음운 경로 또는 간 접 경로로, 심성어휘집을 통하지 않고 철자-음소 변환(graphemeto-phoneme conversion) 과정을 거쳐 처리하는 것이다. 정상 성인 은 이 과정에 관여하는 모든 요소가 정상적으로 기능하지만, 실어 증 환자의 경우 뇌손상으로 인해 이 과정에 문제가 생겨 읽기 결함 이 나타난다.

이중경로모형에 근거하여 뇌손상으로 인한 읽기 결함 유형은 세 가지로 나눌 수 있다. 먼저 음운성 실독증(phonological dyslexia) 은 음운 경로의 손상으로 인해 철자-음소 변환 능력의 문제로 단어 에 비해 비단어의 읽기 수행이 저하되는 특징을 보이는 유형이다 (Basso, 2003). 표층성 실독증(surface dyslexia)은 규칙 단어 및 비 단어의 읽기 수행에 비해 불규칙 단어의 읽기 수행이 저하되는 특 징을 보이는 유형이며(Rapcsak \& Beeson, 2004), 이는 어휘 경로의 손상으로 인해 비어휘 경로에 의존하여 문자 자극을 처리하는 것 에 기인한다. 마지막으로 심층성 실독증(deep dyslexia)이다. 이 유 형은 비어휘 경로와 의미시스템의 손상으로 인해 나타나는 다요소 적 증상으로, 단어를 의미적으로 관련이 있는 다른 단어로 읽는 의 미 착어 오류가주된 특징이다.

한글은 표음 문자로, 가운데 모음을 중심으로 앞뒤에 자음이 결 합되는 모아쓰기(예: 한글 $\rightarrow$ 한글)의 특징을 가지기 때문 에 글자의 수와 음절의 수가 일치한다. 또한 각 자소는 하나의 음소 를 가지며, 철자-음소의 규칙적 대응으로 인해 한 음절 내에서는 표 기 그대로 소리가 나지만, 음절과 음절 사이에서 음운 변동 현상이 일어나기도 한다는 특징을 갖는다(Lim, 2006). 따라서 한글은 철 자-음소 대응관계가 완전히 규칙적이거나 불규칙적이지 않은 언어 이며, 음운 규칙이 적용되어 철자-음소 대응이 불일치하는 경우에
읽기는 주로 어휘 경로를 통해 이루어진다고 보고되고 있다(Lee, Kim, \& Kang, 2003; Nam, Kim, \& Seo, 2001).

실어증 환자들을 대상으로 한 읽기 평가 관련 연구는 1970년대 부터 영어권에서 더욱 활발하게 이루어져왔다(Beauvois, \& Dérouesné, 1979; Coltheart, Masterson, Byng, Prior, \& Riddoch, 1983; Funnell, 1983; Marshall \& Newcombe, 1966, 1973; Patterson, 1982; Patterson, Marshall, \& Coltheart, 1985; Shallice, Warrington, \& McCarthy, 1983; Warrington, \& Shallice, 1980). Funnell (1983)은 구체성, 규칙성, 형태론적으로 복잡한 단어, 문법형태소 등 다양한 영역의 단어 읽기에서 $85 \%$ 의 정반응률을 보인 반면 비단어는 모두 오반응을 보인 환자 사례를 통해 단어와 비단어의 불일치를 보고 하며, 음운성 실독증 환자의 읽기 수행은 어휘의 의미성에만 영향 을 받는 것을 밝혔다. Bub, Cancelliere과 Kertesz (1985)는 뇌손상 전에 정상적인 읽기 능력을 보유했던 환자가 규칙 단어와 비단어 읽기에서 높은 수행률을 보이는 반면 불규칙 단어에서 상당한 규 칙화 오류를 보였다고 밝혔으며, 불규칙 단어 읽기에서 주요한 변 수는 단어 빈도임을 보고하였다. 국내 연구로 Cho와 Pyun (2015) 은 페리실비안(perisylvian) 영역에 손상이 있는 실어증 환자와 정 상군의 읽기 능력을 비교하였다. 그 결과 철자처리, 의미처리, 단어 및 비단어 읽기 영역에서 정상군에 비해 유의하게 수행률이 낮았으 며, 그 중 단어에 비해 비단어의 읽기 수행률이 유의하게 낮은 음운 성 실독증의 패턴을 밝혔다. Cho (2005)는 실어증 환자 2명을 대상 으로 구체어 및 추상어, 비단어를 규칙 및 불규칙 조건으로 자극을 선정하여 읽기 과제를 실시하였고, 단어에 비해 비단어의 수행이 현저하게 떨어짐을 보고하였다. 이 결과 역시 음운성 실독증의 특 징에 근접하며, 철자-음소 변환 경로의 선택적 손상으로 인한 결과 로 보았다.

이외에도 국내에서 실어증 환자를 대상으로 한 읽기 연구가 진행 되고 있으나, 정상군과 실어증 환자를 대상군으로 읽기 수행률을 비교한 연구는 찾아보기 어렵다. 비교적 적은 대상자수의 사례 연 구가 대부분으로 실어증 집단의 읽기 결함의 특징으로 보기 어렵 다. 또한 이중경로모형에 근거하여 읽기에 영향을 미칠 수 있는 요 소와 한글이 가진 특성을 고려하여 제작한 자극으로 한 실험은 제 한적이다.

이에 따라 본 논문에서는 한글 읽기 모형으로 적합한 이중경로 모형에 근거하여 실어증 환자의 읽기 결함을 알아보고자 의미성 및 규칙성에 따라 단어와 비단어, 규칙과 불규칙 조건으로 읽기 능력 을 평가하고자 한다. 읽기에 영향을 미칠 수 있는 품사, 음절 수, 빈 도, 음운유사성, 한자어와 고유어, 추상어와 구체어에 따른 영향을 배제하고자 한다. 발병 전에 정상적인 읽기 활동이 가능했다는 점 
을 고려하여 실어증 환자의 읽기 수행력을 정상군과 비교하고, 의 미성과 규칙성에 따른 읽기 변인 중 실어증 중증도를 가장 잘 예측 할 수 있는 변인에 대해 알아보고자 한다. 또한 실어증 환자의 읽기 오류 유형을 이중경로모형에 근거하여 파악함으로써 실어증 환자 의 읽기 결함의 특징을 고찰해보고자 한다.

본 연구의 구체적인 질문은 아래와같다.

첫째, 어휘의 의미성(단어 vs. 비단어) 및 철자-음소 대응 규칙성 (규칙 vs. 불규칙)에 따라 실어증 환자와 정상 집단 간 명사형 자극 읽기 정반응률에 차이가 유의한가?

둘째, 어휘의 의미성 및 규칙성에 따른 명사형 자극 읽기 수행력 중 실어증 중증도를 유의하게 예측하는 변인은 무엇인가?

셋째, 읽기 과제에서 실어증 환자군에서 나타난 읽기 오류의 유 형별 비율은 어떠한가?

\section{연구 방법}

\section{연구 대상}

본 연구의 대상자는 한국어를 모국어로 사용하는 실어증 환자 20 명과 정상 성인 20 명이다.

실어증 환자는 (1) 좌뇌의 피질 및 피질하 부위의 뇌졸중에 기인 한 언어장애를 보이는 자, (2) Korean version of the Western Aphasia Battery (K-WAB; Kim \& Na, 2001) 결과, McNeil과 Pratt (2001) 의 실어증 정의에 근거하여 전반적인 언어 하위 유형에서 어려움을 보이는 자, (3) 발병 전 주 손잡이가 오른손이었으며 현재 시력 혹은 교정시력이 정상인 자, (4) 발병 전 뇌손상 및 기타 신경학적 질환이 없었다고 보고된 자, (5) 무학이 아니며 발병 전 정상적인 읽기 능력 을 보유한 대상자로 선정하였다. (6) 중도 이상의 말실행증 (apraxia of speech) 또는 마비말장애로 말명료도가 저하되어 있는 환자는 제외하였다.

정상 성인은 (1) 실어증 환자 집단과 평균 연령 및 평균 교육연수 가 일치하는 자, (2) 한국판 간이정신상태검사(Korean version of Mini Mental State Examination, K-MMSE; Kang, Na, \& Hahn, 1997) 결과가 정상 범위에 속하는 자, (3) 그 외에 언어 및 신경학적 손상, 병력이 보고되지 않은 자, (4) 오른손잡이이고 시력 혹은 교정 시력이 정상인 자, (5) 무학이 아니며 본인 보고에 따라 단어 이상의 읽기가 가능한 대상자로 선정하였다.

본 연구에 참여한 집단별 대상자 정보를 요약하여 Table 1에 제 시하였으며, 자세한 정보는 Appendices 1과 2에 제시하였다. 집단 간 연령과 교육년수에 통계적으로 유의한 차이가 있는지 알아보기 위해 각각 독립표본 $t$-검정(two-independent samples $t$-test)을 실시
Table 1. Descriptive information on participants

\begin{tabular}{lcc}
\hline & Normal controls group & Participants with aphasia \\
\hline Age (yr) & $58.45(12.48)$ & $59.90(11.19)$ \\
Education (yr) & $13.20(3.72)$ & $12.70(2.36)$ \\
\hline
\end{tabular}

Values are presented as mean (SD).

하였고, 두 집단의 연령 및 교육년수의 차이가 각각 통계적으로 유 의하지 않은 것으로 나타났다.

\section{실험 자극}

본 연구과제는 의미성에 따라 단어 및 비단어, 음운 규칙 적용 여 부에 따라 규칙 및 불규칙 자극을 선정하였다. Nam 등(1997)에서 음절길이에 따라 수행력의 차이가 있다고 보고하였으므로, Lee (2001)에 의해 우리말 어휘 중 가장 빈도가 높다고 보고된 2음절로 구성하였다. 또한 단어에서 품사에 따른 차이가 과제 수행에 미칠 수 있는 영향을 배제하기 위해 모두 명사형으로 선택하였다.

의미성에 따라 의미가 있는 단어는 연세대학교 언어정보개발연 구원에서 간행한 "연세 말뭉치 1-9를 대상으로 한 현대 한국어의 어휘 빈도 - 빈도 7 이상-"에서 규칙 단어 16 개, 불규칙 단어 16 개를 빈도수에 유의한 차이가 없도록 선정하였다. 또한 구체어와 추상 어, 한자어와 고유어를 동일한 개수로 선정하여, 이로 인한 읽기 수 행력의 영향을 줄이고자 하였다. 의미가 없는 비단어는 음운유사 성에 따라 높거나 낮은 자극의 개수를 동일하게 선정하였다. 의미 가 없는 비단어에서 규칙 비단어는 Jung (2015)에 등재되어 있는 비 단어 중 음운유사성이 높은 것과 낮은 것을 각각 8개씩 선정하였 다. 불규칙 비단어 중 음운유사성이 높은 것은 Jung (2015)에서 사 용한 방법과 동일하게 불규칙 단어의 첫 음절의 어두 초성을 조음 방법이나 위치가 같은 음소로 바꾸어 제작하였다. 음운유사성이 낮은 불규칙 비단어는 Lee (2003)에서 사용한 자극 중 각 음운변동 유형에 해당하는 것으로 선정하였다. 이는 단어의 음소를 조작하 여 비단어로 바꾼 것이 아닌, 비단어로서 제작된 것이므로 음운유 사성이 낮다고 판단하였다.

규칙성에 따라 철자-음소 대응 규칙이 적용되는 규칙 조건과 음 운 규칙이 적용되어 음운 변동이 일어나는 불규칙 조건으로 나뉜 다. 불규칙 조건은 정확한 분석을 위해 어느 한 음소가 다른 음소 로 바뀌는 대치 현상중에서 선정하였다. Lee (1990)는 "국어대사전 (개정판) (이희승 편)"에서 각 페이지 왼쪽 맨 밑 어항을 임의로 선 정하여 총 4,370 개의 어항에 적용되는 규칙들의 빈도를 조사하였 고, 이 중 탈락, 축약, 첨가를 제외하고 대치현상에 포함되는 것은 경음화, 비음화, 격음화, 유음화, 구개음화, 변자음화이다. 이 가운 
데 발생빈도 백분율 $0.3 \%$ 이상이며 명사형에 적용하기 적합하다고 판단되는 경음화, 비음화, 유음화를 선택하였다. 단, 본 연구에서는 연음화가 음절과 음절 사이에서 앞에 종성과 뒤의 모음이 만났을 때 음소가 이동하며 음가가 변화된다는 점에서 대치현상에 보다 가깝다고 보았으며, 발생빈도가 $3.1 \%$ 로 비교적 높은 편에 속하고 분석의 정확도가 높을 것으로 판단하여 포함시켰다.

단어와 비단어를 각각 32 개씩 선정하였고, 각 항목은 음운 규칙 적용 여부에 따라 규칙 16 개, 불규칙 16 개로 나뉜다. 따라서 전체 자극은 총 64 개의 항목으로 이루어져 있으며, 아래와 같은 요인을 반영하여 제작하였다. 실험에서 사용한 읽기 자극 목록은 Appen$\operatorname{dix} 3$ 에 제시하였다.

\section{연구 절차}

본 연구의 선별검사 단계에서는 대상자의 적합성 판단 및 기초 자료 수집과 실험에 대한 동의 및 설명이 이루어졌다. 정상 집단은 선별검사로 K-MMSE를, 실어증 환자 집단은 K-WAB을 실시하였 고, 본 연구 대상자에 해당하지 않는 자는 연구대상에서 제외하였 다. 선별검사가 끝난 후, 연구자는 연구 대상자에게 “제시된 글자를 읽어 주십시오.”라고 요청하고, 목표어를 하나씩 제시하였다. 대상 자가 읽지 못하겠다는 의사를 표하거나 20초 이상 반응이 없는 경 우, 기록지에 무반응으로 표시하고 다음 목표어를 제시하였다. 대 상자가 여러 번 자가수정을 할 경우, 최종 반응으로 기록 및 채점하 였다. 연구자는 대상자의 반응을 녹음하는 동시에 기록지에 정반 응 여부를 기록하였다.

\section{자료 분석}

\section{정확도(accuracy)}

실험이 종료된 후, 녹음한 파일로 대상자의 반응을 전사하고, 정 반응 한 경우 1 점, 오반응 한 경우 0 점으로 계산하였다. 정반응률 (\%)은 정반응 한 문항 수를 전체 문항수인 64로 나눈 후 100 을 곱 하여 계산하였다.

\section{오류 유형(error type)}

실어증 집단의 오반응을 해당 오류 유형으로 분류하여 총계를 내고, 해당 오류 유형의 개수를 전체 오류 개수로 나누고 100 을 곱 하여 백분율을 계산하였다.

각 조건 내에서 오류 유형의 비율을 계산하기 위해, 오류 유형별 개수를 각 조건의 전체 오류로 나누고 100 을 곱해 백분율을 계산 하였다.

오류 유형은 Benson과 Ardila (1996)와 Baik (2004)를 참고하여
본 연구의 목적에 맞게 적절하게 재구성하였으며, 실어증 집단을 대상으로 분석하였다. 오류 유형은 단어 조건, 비단어 조건으로 나 뉜다. 먼저 단어 조건에서의 오류로는 단어를 단어로 읽는 양상이 있으며, 여기에는 (1) 시각적으로 비슷한 음소로 이루어진 단어로 읽는 시각 착어, (2) 의미적 연관이 있는 다른 단어로 읽는 의미 착 어, (3) 의미적 연관이 없는 비관련 단어로 읽는 의미 착어 오류, (4) 불규칙 단어를 음운 변동 규칙을 적용하지 않고 읽는 규칙화 오류 가 해당된다. 단어를 비단어로 읽는 오류 양상의 경우, (1) 음소 또 는 음절을 대치하여 비단어로 읽는 경우와 (2) 신조어(모든 자음과 모음이 바뀌었거나, 음절 수에 변화가 있거나, 전사가 불가능한 경 우)가 해당된다. 기타에는 무반응과 보속현상이 해당된다. 비단어 조건에서의 오류 중 비단어를 비단어로 읽는 양상에는 (1) 음소 또 는 음절을 대치하여 비단어로 읽는 오류, (2) 불규칙 비단어를 음운 변동 규칙을 적용하지 않고 읽는 규칙화 오류, (3) 신조어가 해당된 다. 비단어를 단어로 읽는 양상에는 어휘화가 해당된다. 기타에는 단어 조건과 마찬가지로 무반응과 보속현상이 해당된다. Appen$\operatorname{dix} 4$ 에 구체적인 예시와 함께 오류 유형을 정리하였다.

\section{자료의 통계적 처리}

자료의 통계적 처리는 SPSS (Statistics Package for the Social Science ver. 18.0)를 사용하였다. (1) 의미성(단어 vs. 비단어) 및 규칙성 (규칙 vs. 불규칙)에서 실어증 환자 집단과 정상 성인 집단 간 읽기 정 반응률에 차이가 있는지 알아보기 위해 삼원혼합분산분석(threeway mixed ANOVA)를 실시하였다. (2) 실어증 중증도와 의미성 및 규칙성에 따른 읽기 변인 간 상관관계를 알아보기 위해 Pearson 상 관계수를 산출하고, 읽기 변인 중 실어증 중증도를 가장 잘 예측할 수 있는 것을 알아보기 위해 회귀분석(stepwise regression analysis) 을 실시하였다.

\section{신뢰도}

본 연구의 읽기 점수에 대한 신뢰도를 검증하기 위해 평가자 간 신뢰도를 산출하였다. 연구자가 평가 및 채점을 실시하였으며, 채점 에 대한 신뢰도를 검증하기 위해 제 2 평가자로 언어병리학과 소속 대학원생 2 명이 참여하였다. 연구자는 제 2 평가자에게 녹음된 파일 을 보고 전사 및 채점을 하도록 하였으며, 미리 오류 유형을 숙지하 도록 하고 오반응을 유형에 따라 분류하도록 하였다. 전사에 대한 신뢰도는 96.5\%였고, 오류 유형에 대한 신뢰도는 94.7\%였다. 신뢰 도는 일치한 문항 수를 전체 문항 수로 나누고 100 을 곱하여 산출 하였다. 


\section{연구 결과}

\section{실어증 환자의 의미성 및 규칙성에 따른 명사형 자극 읽기 정반응률에서 집단 간 차이 분석 결과}

실어증 환자와 정상 성인 집단 간 의미성(단어 vs. 비단어) 및 규 칙성(규칙 vs. 불규칙)에 따른 명사형 자극 읽기 정반응률의 분석 결과는 Figure 1 과 같다.

의미성 및 규칙성에 따른 명사형 자극 읽기 정반응률에 그룹 간 차이가 있는지 알아보기 위해 삼원혼합분산분석(three-way mixed ANOVA)을 실시한 결과, 실어증 집단과 정상 집단 간주효과가 통계 적으로 유의하였다 $\left(F_{(1,38)}=47.932, p<.001\right)$. 즉, 정상 집단의 정반응 률이 실어증 환자의 정반응률보다 유의하게 높은 것으로 나타났다. 의미성에 대한 주효과도 통계적으로 유의하였다 $\left(F_{(1,38)}=160.136\right.$, $p<.001)$. 즉, 단어 읽기 정반응률이 비단어 읽기 정반응률에 비해 유 의하게 높았다. 또한 규칙성에 대한 주효과가 통계적으로 유의하였 다 $\left(F_{(1,38)}=33.523, p<.001\right)$. 즉 규칙 단어 또는 비단어 읽기 정반응률 이불규칙 읽기 정반응률에 비해 유의하게 높은 것으로 나타났다.

의미성과 집단 간의 이차 상호작용이 통계적으로 유의하였다 $\left(F_{(1,38)}=31.157, p<.001\right)$. 실어증 집단에서 의미성에 따른 정반응률 의 차이가 정상 집단의 정반응률의 차이보다 유의하게 큰 것으로 나타났다. 즉 정상 집단에 비해 실어증 집단의 경우 단어에 비해 비 단어에서 수행력 저하가 유의하게 더 크게 나타났다. 의미성과 규칙 성 간의 이차상호작용이 통계적으로 유의하였다 $\left(F_{(1,38)}=9.055\right.$, $p<.01)$. 즉 단어에 비해 비단어의 경우 규칙보다 불규칙 읽기에서 수행력 저하가 유의하게 더 크게 나타났다.

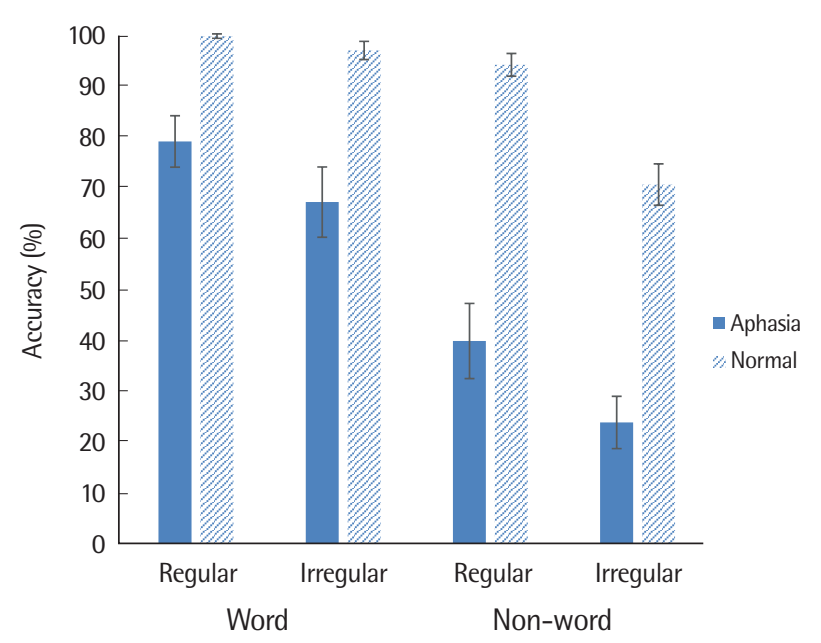

Figure 1. Accuracy on reading tasks depending on the regularity and lexicality for each group.
반면 규칙성과 집단에 대한 이차상호작용 $\left(F_{(1,38)}=.28, p>.05\right)$ 과 의미성 및 규칙성에 따른 집단 간 읽기 정반응률의 차이에 관한 삼 차상호작용이 통계적으로 유의하지 않았다 $\left(F_{(1,38)}=4.076, p>.05\right)$

\section{의미성 및 규칙성에 따른 명사형 자극 읽기 정반응률과 실어증 중증도 간 상관관계 및 예측 변인 분석}

의미성 및 규칙성에 따른 명사형 자극 읽기 정반응률과 실어증 중증도(AQ) 간 상관관계를 살펴보기 위해 Pearson 상관계수를 산 출하였다. 상관 계수에 대한 결과는 Table 2에 제시하였다.

실어증 중증도와 의미성 및 규칙성에 따른 명사형 자극 읽기 변 인 간 상관관계를 분석한 결과, 규칙 비단어 $(r=.711, p<.01)$, 불규 칙 단어 $(r=.620, p<.01)$, 규칙 단어 $(r=.569, p<.01)$ 순으로 유의한 상관이 나타났다. 반면 불규칙 비단어는 유의한 상관이 나타나지 않았다 $(r=.443, p>.05)$.

의미성 및 규칙성에 따른 읽기 변인 중에서 실어증 중증도를 가 장 잘 예측하는 변인이 무엇인지 살펴보기 위해 $\mathrm{AQ}$ 를 종속변수로, 의미성 및 규칙성에 따른 읽기 변인(규칙 단어, 불규칙 단어, 규칙 비단어, 불규칙 비단어)을 독립변수로 단계적 회귀분석(stepwise regression analysis)을 실시하였다. 실어증 집단의 중증도를 유의하 게 예측하는 변인에 대한 회귀분석은 Table 3 과 같다.

실어증 중증도를 가장잘 예측하는 변인은 규칙 비단어였다 $\left(F_{(1,15)}=\right.$ $18,350, p<.001)$. 즉, 규칙 비단어의 읽기가 실어증 집단의 중증도 를 약 $47.7 \%$ 예측하는 것으로 나타났다.

\section{실어증 집단의 읽기 오류 유형별 비율}

실어증 집단의 읽기 오류 유형을 분석한 결과를 Table 4에 제시 하였다. 실어증 집단의 읽기 오반응 비단어 조건의 오류가 단어 조 건보다 두 배 이상 많았다. 전체 오류 중 오류 유형별 비율은 비단어 를 비단어로 대치, 비단어에서 기타, 단어를 비단어로 대치, 단어에

Table 2. Correlation coefficients among $A Q$ and reading variables on lexicality and regularity

\begin{tabular}{lcccc}
\hline & $\begin{array}{c}\text { Regular } \\
\text { word }\end{array}$ & $\begin{array}{c}\text { Irregular } \\
\text { word }\end{array}$ & $\begin{array}{c}\text { Regular } \\
\text { non-word }\end{array}$ & $\begin{array}{c}\text { Irregular } \\
\text { non-word }\end{array}$ \\
\hline $\mathrm{A} 0$ & $.569^{* *}$ & $.620^{* *}$ & $.711^{* *}$ & .443 \\
\hline${ }^{* *} p<.01$. & & & & \\
\end{tabular}

Table 3. Results of stepwise regression predicting severity of aphasia

\begin{tabular}{lcccc}
\hline & $\mathrm{B}(\mathrm{SE})$ & $\mathrm{R}^{2}$ & $\Delta \mathrm{R}^{2}$ & $p$-value \\
\hline Regular non-word & $.448(.105)$ & .505 & .477 & $.000^{* * *}$ \\
\hline$* * * 0<001$. & & & &
\end{tabular}



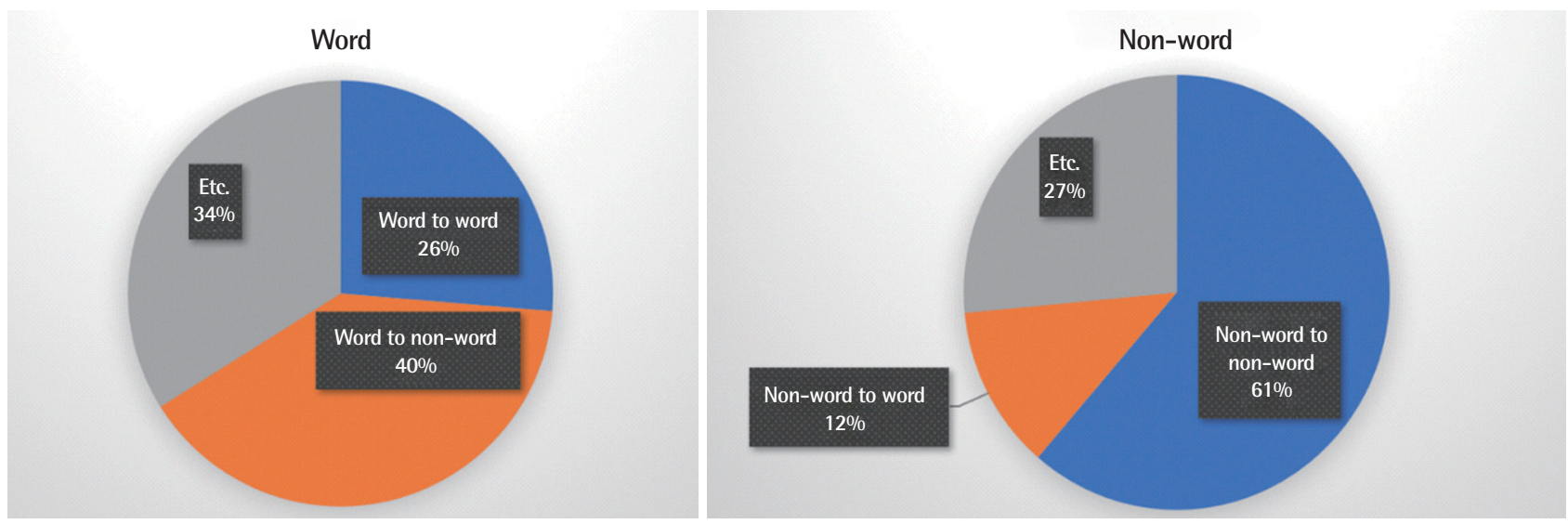

Figure 2. Ratio of error types for each word and non-word condition.

Table 4. Descriptive analyses depending on error types in persons with aphasia

\begin{tabular}{|c|c|c|}
\hline Error type & Frequency & Ratio (\%) \\
\hline Word & 171 & 28.26 \\
\hline \multicolumn{3}{|l|}{ Word $\rightarrow$ word } \\
\hline Visual paralexia & 12 & 1.98 \\
\hline Semantic paralexia & 10 & 1.65 \\
\hline Unrelated word & 7 & 1.16 \\
\hline Regularization & 16 & 2.64 \\
\hline \multicolumn{3}{|l|}{ Word $\rightarrow$ non-word } \\
\hline Non-word & 68 & 11.24 \\
\hline \multicolumn{3}{|l|}{ Etc. } \\
\hline Neologism & 27 & 4.46 \\
\hline No response & 30 & 4.96 \\
\hline Preservation & 1 & .17 \\
\hline Non-word & 434 & 71.74 \\
\hline \multicolumn{3}{|l|}{ Non-word $\rightarrow$ non-word } \\
\hline Non-word & 202 & 33.39 \\
\hline Regularization & 64 & 10.58 \\
\hline \multicolumn{3}{|l|}{ Non-word $\rightarrow$ word } \\
\hline Lexicalization & 53 & 8.76 \\
\hline \multicolumn{3}{|l|}{ Etc. } \\
\hline Neologism & 19 & 3.14 \\
\hline No response & 92 & 15.21 \\
\hline Preservation & 4 & .66 \\
\hline Total & 605 & 100 \\
\hline
\end{tabular}

서 기타, 비단어를 단어로 대치, 단어를 단어로 대치 순이었다.

먼저 비단어 조건 내 오류 유형별 비율을 살펴보면, 음소 또는 음 절을 대치하여 비단어로 읽는 오류가 가장 많았으며, 무반응, 규칙 화, 어휘화, 신조어, 보속현상 순이었다. 단어 조건 내 오류 유형 중 가장 많은 유형은 단어를 비단어로 읽는 것이었고, 무반응, 신조어, 규칙화, 시각 착어, 의미 착어, 의미적 연관이 없는 비관련 단어로 읽음, 보속현상 순이었다. Figure 2에 단어 조건과 비단어 조건 내에
서 오류 유형별 비율을 각각 그래프로 제시하였다.

\section{논의 및 결론}

본 연구에서는 한글의 다양한 특징을 고려하여 선정한 명사형 자극으로 실어증 집단의 읽기 결함 특성을 연구하고자 하였다. 실 어증 환자는 발병 전 단어 수준 이상에서 기능적 읽기가 가능하였 으므로 정상 집단과 비교하여 읽기 능력의 차이를 알아보고자 하 였다. 또한 다양한 중증도의 실어증 환자를 대상으로 실어증 환자 의 집단의 특성을 알아보고자 하였다. 본 연구 결과 실어증 환자와 정상 집단 간 2음절 명사형 자극 읽기 능력에 차이가 있으며, 정상 집단에 비해 실어증 환자가 읽기에 더 어려움을 보인다는 것을 의 미한다. 이는 실어증 환자는 대부분 읽기에 어려움이 나타나는 후 천성 실독증의 증상을 보이며(Patterson \& Marcel, 1977; Rosenbek et al., 1989), 정상 성인은 읽기 과정에 관여하는 모든 요소가 정상 적으로 기능하는 반면, 실어증 환자는 뇌손상으로 인해 이러한 과 정 중 일부의 선택적 손상으로 인해 읽기에 어려움을 보인다는 것 을 의미한다.

또한 의미성에 따른 집단 간의 읽기 정반응률의 차이가 유의하 였으며, 이는 실어증 집단에서 단어에 비해 비단어의 읽기 능력이 저하되는 어휘성 효과가 정상 집단에 비해 더 크게 나타난다는 것 을 의미한다. 실어증 환자의 경우에도 우선 문자 자극을 보고 철자 열을 철자어휘집에서 찾아 심성어휘집에서 의미와 연결 짓는 과정 을 거친다고 볼 수 있다. 비단어의 경우 이 과정을 통해 연결되는 의 미가 없으므로 철자-소리 변환 규칙을 적용해야 하는데 실어증 환 자는 이 능력이 정상에 비해 특히 저하되어 있음을 알 수 있다. 이러 한 결과는 단어에 비해 비단어의 읽기에서 더 어려움을 보이는 음운 성 실독증 유형의 특징과 유사하다(Beauvois \& Dérouesné, 1979; 
Cho, Jung, \& Nam, 2002; Cho, 2005; Cho \& Pyun, 2015; Patterson, 1982; Warrington \& Shallice, 1980). Cho와 Pyun (2015)에서는 페 리실비안 영역에 손상이 있는 실어증 환자 5명을 대상으로 음운성 실독증의 특징을 패턴을 밝혔다면, 본 연구에서는 20 명의 손상 영 역 및 실어증 중증도가 다양한 실어증 환자군에게서 한글의 특징 을 반영한 명사형 자극 읽기를 제시하였을 때, 전반적으로 단어에 비해 비단어 읽기의 어려움이 나타나는 것을 알 수 있다. 본 연구 결 과, 정상 집단의 경우에도 단어에 비해 비단어 읽기에서 정반응률 이 낮은 경향을 보이며, 이는 정상 집단을 대상으로 한 Park (1993) 과 Yi (1996)의 연구 결과와 일치한다. 다만 본 연구 결과는 이러한 어휘성 효과가 정상 집단에 비해 언어 결함을 보이는 실어증 집단 에서 더욱 크게 나타나는 것을 시사한다.

반면 규칙성에 따른 집단 간 읽기 정반응률의 차이는 통계적으 로 유의하지 않았으며, 의미성 및 규칙성에 따른 읽기에서 집단 간 상호작용 효과가 유의하지 않았다. 두 집단 모두 규칙 자극에 비해 불규칙 자극에서 정반응률이 낮았으나, 이러한 규칙성 효과가 실 어증 환자와 정상 집단 간의 유의하지 않다는 것을 의미한다. Seidenberg, Waters, Barnes와 Tanenhaus (1984)는 불규칙 단어 읽기 에서 주요한 변수는 단어 빈도임을 보고하였다. 정상 집단을 대상 으로 한 Yi (1996) 연구에서는 저빈도 단어 읽기에서 규칙성 효과 를 보고하였으며, 고빈도 단어에서는 나타나지 않았다. 실어증 환 자 4명을 대상으로 2음절 단어 읽기를 연구한 Cho와 Nam (2002)에 서도 유의미한 규칙성 효과를 발견하지 못하였다. 본 연구에서 사 용한 불규칙 단어는 빈도에서 유의미한 차이가 없도록 선정하였다. 또한 선행연구와 달리 본 연구에서는 불규칙 비단어가 포함되어 있 으며, 비단어는 음운유사성을 통제하여 선정하였으므로 빈도의 영향이 보다 통제되어 있다고 볼 수 있다. 따라서 정상 집단에서 규 칙성 효과가 나타나지 않았으며, 국내 선행연구와 마찬가지로 실어 증 집단에서도 유의미한 규칙성 효과가 나타나지 않은 것으로 해석 할수 있다.

실어증 중증도와 의미성 및 규칙성에 따른 읽기 변인 간 상관관계 를 분석한 결과, 규칙 비단어, 불규칙 단어, 규칙 단어 순으로 유의한 상관이 나타났다. 반면 불규칙 비단어는 유의한 상관이 나타나지 않았는데, 이는 실어증 중증도와 관계없이 대부분 모두 낮은 수행 률을 보인 것에 기인한다. 읽기 변인 중 실어증 환자들의 중증도를 보다 잘 예측하는 변인을 살펴본 결과, 실어증 중증도와 가장 높은 상관을 보인 변인은 규칙 비단어였으며, $47.7 \%$ 의 예측력을 가졌다.

규칙 비단어가 실어증 중증도를 유의하게 예측하는 것은 앞서 연구문제 1 에서 확인했던 어휘성 효과와 그 맥락을 같이 한다. 실어 증 환자는 단어에 비해 비단어의 읽기 수행률이 크게 저하되며, 이
것이 중증도와 관련 있다는 것은 전반적인 언어능력의 손상 정도 에 따라 철자-음소 변환 능력의 손상 정도가 정적 상관성을 보인다 고 볼 수 있다. 실어증 환자는 전반적인 언어 능력에 손상을 보이며, 본 연구에서 실어증 중증도를 측정하기 위해 사용한 $\mathrm{AQ}$ 점수에는 유창성, 이해하기, 따라말하기, 이름대기 점수가 포함되며, 읽기 능 력은 포함되어 있지 않다. 즉, 읽기가 포함되지 않은 실어증의 전반 적인 언어의 표현 및 이해 영역의 결함 정도와 읽기 과정 중에서도 특히 철자-음소 변환 능력과 관련이 있다는 것을 시사한다.

불규칙 비단어에 비해 규칙 비단어가 실어증 중증도를 가장 잘 예측할 수 있는 것은 중증도와 무관하게 실어증 집단에서 불규칙 비단어의 수행률이 모두 저조한 것에 기인했다고 해석할 수 있다. 실어증 환자의 중증도에 따라 경도한 수준의 언어 결함을 보이는 환자의 경우 불규칙 비단어를 제외한 나머지 조건에서 정상 성인의 읽기 수행력과 크게 차이나지 않았다.

다만, 불규칙 비단어의 경우 음운 변동 규칙 적용에서 한계가 있 다. Lee과 Kim (2003)은 단어 및 비단어의 음운 규칙의 적용 용이 성에 대해 연구하였는데, 단어에서는 음운 규칙이 선정한 유형별로 고르게 적용되었으나, 비단어의 경우에는 음운 규칙의 유형에 따 라 다른 결과가 나타났다. 즉 본 연구에서 사용된 불규칙 비단어의 경우 음운 규칙 유형에 따라 적용 용이성이 달라 읽기 과정에 각자 다른 영향을 미쳤을 수 있다. 또한 불규칙 비단어의 경우 어휘 경로 와 비어휘 경로의 상호작용을 통해 이루어져야 하기 때문에 불규칙 단어에 비해음운 규칙의 적용이 모호해질 수 있다.

실어증 집단의 읽기 오류를 유형별로 분석한 결과, 실어증 집단 의 읽기 오반응 중 비단어 조건의 비율은 $71.74 \%$ 로 단어 조건의 비 율 $28.26 \%$ 보다 많았다. 단어에 비해 비단어의 오류가 두 배 이상 많 았다는 것은 실어증 환자의 경우에도 손상된 언어 능력으로 인해 읽기 결함을 보이지만, 심성어휘집을 통해 기존의 어휘 지식을 어 느 정도 활용할수 있다고 볼수 있다.

전체 오류 유형 및 비단어 조건 내에서 가장 많은 오류 유형인 음 소 또는 음절을 대치하여 읽는 것은 비단어를 심성어휘집에서 연결 되는 의미가 없는 비단어임을 인식하고 철자-음소 변환 과정을 거 쳐 읽으려고 시도하였으나 이 과정의 손상으로 인해 정확한 처리가 이루어지지 못했다고 해석할수 있다.

비단어에서 무반응은 비단어임을 인지하고 읽기를 시도하지 않 았거나 불가했던 오류 유형으로, 전체 오류 유형 및 비단어 조건 내 에서도 두 번째에 해당한다. 이는 단어 조건 내에서 무반응보다 더 많은 비율을 차지하며, 의미가 연결되는 단어에 비해 의미가 없는 비단어의 경우 읽기 시도를 포기하거나 불가능했던 비율이 상대적 으로 높다고 볼 수 있다. 규칙화 오류는 비단어 조건에서 $10.58 \%$, 
Woon Jeong Kim, et al. • Effects of Lexicality and Regularity on Reading in Aphasia

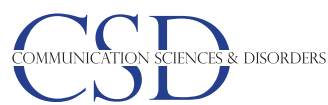

단어 조건에서 $2.64 \%$ 로 나타났다. 즉, 비단어에서 음운 변동 규칙 을 적용하는 것이 단어 조건에 비해 상대적으로 어려움을 의미한 다. 불규칙 비단어의 경우 어휘 경로와 음운 경로가 서로 상호작용 을 통해 이루어져야 하므로 더 많은 규칙화 오류가 나타났다고 볼 수 있다.

본 연구에서는 특정 뇌손상 부위 또는 실어증 유형이 아닌 다양 한 손상 영역 및 중증도를 보이는 실어증 환자들이 보이는 전반적 인 읽기 오류 특성을 분석하였으므로, 추후에는 실어증 유형 또는 손상 부위에 따라 대상자를 선정하여 읽기 특징을 밝힐 필요가 있 다. 또한 본 연구에서는 2음절어를 자극으로 하여 읽기 능력을 평 가하였으므로, 다양한 음절 수의 자극 또는 단어 이상의 수준에서 의 읽기 수행력을 평가하는 후속 연구를 통해 실어증 환자의 한글 읽기 특징을 확장하여 밝힐 필요가 있다.

본 연구 결과를 통해 실어증 환자는 뇌손상으로 인해 후천적인 읽기 결함을 보이며, 빈도가 통제되었을 때, 규칙성에 비해 어휘의 의미성에 따라 더 큰 영향을 받는 것을 확인했다. 즉 실어증 환자의 읽기 결함의 범위와 정도는 다양할 수 있으나 전반적으로 단어에 비해 비단어의 읽기 수행력이 저조한 특징을 보이며, 이는 음운성 실독증의 유형과 유사하다. 실어증 중증도를 예측하는 변인은 규 칙 비단어로, 철자-음소 전환 능력의 손상과 전반적인 언어 능력의 손상 정도가 정적 상관관계를 보인다. 이러한 결과는 한글의 특징 과 이중경로모형에 근거하여 실어증 환자의 읽기 능력 및 오류 양 상을 살펴볼 수 있는 기초 자료를 제공한다는 점에서 임상적 의의 가 있다.

\section{REFERENCES}

Baik, Y. (2004). Reading aloud of Chinese-derivative words and pure Korean words in aphasia with dyslexia (Master's thesis). Yonsei University, Seoul, Korea.

Basso, A. (2003). Aphasia and its therapy. New York, NY: Oxford University Press.

Beauvois, M. F., \& Dérouesné, J. (1979). Phonological alexia: three dissociations. Journal of Neurology, Neurosurgery \& Psychiatry, 42, 1115-1124.

Benson, D. F., \& Ardila, A. (1996). Aphasia: a clinical perspective. New York, NY: Oxford University Press.

Bub, D., Cancelliere, A., \& Kertesz, A. (1985). Whole-word and analytic translation of spelling to sound in a non-semantic reader. In K. E. Patterson et al. (Eds.), Surface dyslexia (pp. 15-34). London: Lawrence Erlbaum Associates.
Cho, H., \& Nam, K. C. (2002). Regularity effect shown in aphasic patients. Korean Journal of Communication Disorders, 7, 77-94.

Cho, H., \& Pyun, S. B. (2015). Characteristics of acquired phonological dyslexia in Korean. Communication Sciences \& Disorders, 20, 570-586.

Cho, K. (2005). A case study on the acquired Hangul dyslexia and dysgraphics. Seoul National University Journal of Humanities, 22, 161-179.

Cho, K., Jung, J., \& Nam, K. (2002). Lexical processing in acquired Hangul dyslexia. Korean Journal of Communication Disorders, 7, 1-20.

Coltheart, M. (1978). Lexical access in simple reading tasks. In G. Underwood (Ed.), Strategies of information processing (pp. 151-216). New York, NY: Academic Press.

Coltheart, M., Curtis, B., Atkins, P., \& Haller, M. (1993). Models of reading aloud: dual-route and parallel-distributed-processing approaches. Psychological Review, 100, 589-608.

Coltheart, M., Masterson, J., Byng, S., Prior, M., \& Riddoch, J. (1983). Surface dyslexia. Quarterly Journal of Experimental Psychology, 35, 469-495.

Conklyn, D., Novak, E., Boissy, A., Bethoux, F., \& Chemali, K. (2012). The effects of modified melodic intonation therapy on nonfluent aphasia: a pilot study. Journal of Speech, Language, and Hearing Research, 55, 1463-1471.

Funnell, E. (1983). Phonological processes in reading: new evidence from acquired dyslexia. British Journal of Psychology, 74, 159-180.

Holland, A. (2007). Counseling/coaching in chronic aphasia: getting on with life. Topics in Language Disorders, 27, 339-350.

Humphreys, G. W., \& Evett, L. J. (1985). Are there independent lexical and nonlexical routes in word processing? An evaluation of the dual-route theory of reading. Behavioral and Brain Sciences, 8, 689-705.

Jung, H. (2015). Effect of working memory capacity of elderly groups on phonological similarity and listening conditions on non-word speech perception abilities (Master's thesis). Ewha Womans University, Seoul, Korea.

Kang, Y., Na, D. L., \& Hahn, S. (1997). A validity study on the Korean MiniMental State Examination (K-MMSE) in dementia patients. Journal of the Korean Neurological Association, 15, 300-308.

Kim, H. (2012). Neurogenic speech-language disorders. Seoul: Sigmapress

Kim, H. H., \& Na, D. L. (2001). Paradise.Korean version-Western Aphasia Battery $(K-W A B)$. Seoul: Paradise Welfare Foundation.

Kim, M., Lee, S., \& Jung, B. (2009). Effects of association and imagery on word recognition. Korean Journal of Cognitive Science, 20, 243-274.

Knollman-Porter, K., Wallace, S. E., Hux, K., Brown, J., \& Long, C. (2015). Reading experiences and use of supports by people with chronic aphasia. Aphasiology, 29, 1448-1472. 
Lee, C., Kim, Y., \& Kang, B. (2003). Korean Hangul word recognition at phonological and orthographic level. Korean Journal of Experimental Psychology, 15, 1-17.

Lee, H. (2003). The classification of phonological rules and its adequacy to nonword stimuli: focusing on the representation of the surface and underlying phonological forms (Master's thesis). Seoul National University, Seoul, Korea.

Lee, H., \& Kim, J. (2003). The effects of ease with phonological rules applicability on phonological processing of Korean words and nonwords. Korean Journal of Experimental Psychology, 15, 425-454.

Lee, S. (1990). On the functional load of phonetic/phonological rules: a quantitative survey in modern Korean. Proceedings of the 2nd Annual Conference on Human and Cognitive Language Technology, 131-138.

Lee, S. (2001). Studies on Korean quantitative linguistics. Seoul: Seoul National University Press.

Lim, Y. (2006). A study on the applicability of phonological rules in Hangul word recognition (Master's thesis). Ewha Womans University, Seoul, Korea.

Lynch, K. E., Damico, J. S., Abendroth, K. J., \& Nelson, R. L. (2013). Reading performance subsequent to aphasia: strategies applied during authentic reading. Aphasiology, 27, 723-739.

Marshall, J. C., \& Newcombe, F. (1966). Syntactic and semantic errors in paralexia. Neuropsychologia, 4, 169-176.

Marshall, J. C., \& Newcombe, F. (1973). Patterns of paralexia: a psycholinguistic approach. Journal of Psycholinguistic Research, 2, 175-199.

McNeil, M. R., \& Pratt, S. R. (2001). Defining aphasia: some theoretical and clinical implications of operating from a formal definition. Aphasiology, 15, 901-911.

Nam, K., Kim, J., \& Seo, C. (2001). Form priming effects in Korean visual word recognition. Korean Journal of Experimental and Cognitive Psychology, 13, 21-40.

Nam, K., Seo, K., Choi, K., Lee, K., Kim, T., \& Lee, M. (1997). The word length effect on Hangul word recognition. Korean Journal of Experimental and Cognitive Psychology, 9, 1-18.

Obregon, A. G. (2008). Reimagining literacy competence: a sociopsycholinguistic view of reading in aphasia. In A. D. Flurkey et al. (Eds.), Scientific realism in studies of reading (pp. 85-108). New York, NY: Lawrence Erlbaum Associates.

Park, K. S. (1993). Mental code involved in Hangul word recognition. Korean Journal of Experimental and Cognitive Psychology, 5, 40-55.

Parr, S. (1995). Everyday reading and writing in aphasia: role change and the influence of pre-morbid literacy practice. Aphasiology, 9, 223-238.
Patterson, K. E. (1982). The relation between reading and phonological coding: further neuropsychological observations. In A. W. Ellis (Ed.), Normality and pathology in cognitive function (pp. 77-112). London: Academy Press.

Patterson, K. E., \& Marcel, A. J. (1977). Aphasia, dyslexia and the phonological coding of written words. Quarterly Journal of Experimental Psychology, 29, 307-318.

Patterson, K., Marshall, J. C., \& Coltheart, M. (1985). Surface dyslexia: neuropsychological and cognitive studies of phonological reading. New York, NY: Lawrence Erlbaum Associates.

Rapcsak, S. Z., \& Beeson, P. M. (2004). The role of left posterior inferior temporal cortex in spelling. Neurology, 62, 2221-2229.

Rosenbek, J. C., LaPointe, L. L., \& Wertz, R. T. (1989). Aphasia: a clinical approach. Austin, TX: Pro-Ed.

Sanders, M. (2001). Understanding dyslexia and the reading process: a guide for educators and parents. Boston, MA: Allyn \& Bacon.

Seidenberg, M. S., Waters, G. S., Barnes, M. A., \& Tanenhaus, M. K. (1984). When does irregular spelling or pronunciation influence word recognition? Journal of Verbal Learning and Verbal Behavior, 23, 383-404.

Shallice, T., Warrington, E. K., \& Mccarthy, R. (1983). Reading without semantics. Quarterly Journal of Experimental Psychology, 35, 111-138.

Silverberg, N., Vigliocco, G., Insalaco, D., \& Garrett, M. (1998). When reading a sentence is easier than reading a little' word: the role of production processes in deep dyslexics' reading aloud. Aphasiology, 12, 335-356.

Strauss, S. L. (1999). Learning a first language for the second time: "Goodman Contexts" and "Vygotskyan Zones" in recovery from aphasia. In A. M. Marek \& C. Edelsky (Eds.), Reflections and connections: essays in honor of Kenneth S. Goodman's influence on language education (pp. 403-419). Cresskill, NJ: Hampton Press.

Tae, J., Lee, C., \& Lee, Y. (2015). The effect of the orthographic and phonological priming in Korean visual word recognition. Korean Journal of Cognitive Science, 26, 1-26.

Warrington, E. K., \& Shallice, T. I. M. (1980). Word-form dyslexia. Brain, 103, 99-112.

Webster, J., Morris, J., Connor, C., Horner, R., McCormac, C., \& Potts, A. (2013). Text level reading comprehension in aphasia: what do we know about therapy and what do we need to know? Aphasiology, 27, 1362-1380.

Yi, K. (1996). Phonological rules in oral reading of Korea. Korean Journal of Experimental and Cognitive Psychology, 8, 1-23. 
Appendix 1. 실어증 환자 정보

\begin{tabular}{|c|c|c|c|c|c|c|c|c|c|c|c|}
\hline \multirow[b]{2}{*}{ 번호 } & \multirow[b]{2}{*}{ 연령 } & \multirow[b]{2}{*}{ 성별 } & \multirow{2}{*}{$\begin{array}{l}\text { 교육 } \\
\text { 년수 }\end{array}$} & \multirow{2}{*}{$\begin{array}{l}\text { 발병 후 } \\
\text { 개월 수 }\end{array}$} & \multirow[b]{2}{*}{ 병인 } & \multicolumn{5}{|c|}{ K-WAB } & \multirow[b]{2}{*}{ 실어증 유형 } \\
\hline & & & & & & $\begin{array}{c}\text { 실어증 지수 } \\
\text { (AQ) }\end{array}$ & 유창성 & $\begin{array}{l}\text { 알아 } \\
\text { 듣기 }\end{array}$ & $\begin{array}{l}\text { 따라 } \\
\text { 말하기 }\end{array}$ & $\begin{array}{l}\text { 이름 } \\
\text { 대기 }\end{array}$ & \\
\hline 1 & 55 & $\mathrm{~F}$ & 12 & 34 & Lt. BG ICH & 70 & 4 & 8.5 & 6.4 & 8.1 & Anomic \\
\hline 2 & 55 & M & 12 & 14 & Lt. BG ICH & 77.4 & 6 & 8 & 8.6 & 8.1 & Anomic \\
\hline 3 & 53 & $M$ & 12 & 5 & Lt. MCA & 88.6 & 8 & 8.8 & 9.4 & 9.1 & Anomic \\
\hline 4 & 87 & $M$ & 16 & 7 & Lt. MCA & 68.6 & 5 & 7 & 8.8 & 5.5 & Broca \\
\hline 5 & 78 & $\mathrm{M}$ & 12 & 9 & Lt. MCA & 67.8 & 5 & 8.1 & 5.1 & 7.7 & Conduction \\
\hline 6 & 74 & $\mathrm{~F}$ & 12 & 15 & Lt. SAH/ICH & 77.5 & 7 & 8.95 & 9.8 & 7 & Anomic \\
\hline 7 & 65 & $\mathrm{~F}$ & 6 & 59 & Lt. ICA & 28.4 & 2 & 4.3 & 2.2 & 3.7 & Broca \\
\hline 8 & 51 & M & 12 & 27 & Lt. BG ICH & 26 & 3 & 3.6 & 0.7 & 2.7 & Global \\
\hline 9 & 43 & $M$ & 16 & 19 & Lt. MCA & 37 & 2 & 5.3 & 2.2 & 3.6 & Broca \\
\hline 10 & 59 & $\mathrm{~F}$ & 12 & 24 & Lt. BG ICH & 77.8 & 7 & 7.4 & 8.4 & 8.1 & Anomic \\
\hline 11 & 56 & $M$ & 12 & 25 & Lt. BG ICH & 64.6 & 7 & 7.5 & 6.4 & 4.4 & Conduction \\
\hline 12 & 55 & $\mathrm{~F}$ & 12 & 30 & Lt. SAH & 84 & 8 & 8.5 & 9.8 & 7.6 & Anomic \\
\hline 13 & 48 & M & 16 & 25 & Lt. ICA & 41 & 4 & 4.2 & 3.1 & 5.2 & Broca \\
\hline 14 & 55 & $\mathrm{~F}$ & 12 & 23 & Lt. BG ICH & 67.2 & 5 & 8 & 6.4 & 5.3 & Conduction \\
\hline 15 & 59 & $M$ & 16 & 10 & Lt. MCA & 65 & 5 & 7.9 & 6 & 5.6 & Conduction \\
\hline 16 & 56 & $M$ & 12 & 69 & Lt. BG ICH & 25.8 & 3 & 3.3 & 1 & 2.6 & Global \\
\hline 17 & 51 & $M$ & 16 & 5 & Lt. MCA & 55.8 & 6 & 7 & 5.4 & 4.5 & Conduction \\
\hline 18 & 59 & $\mathrm{~F}$ & 12 & 1 & Lt. brain tumor & 83 & 9 & 8.3 & 8.8 & 7.4 & Anomic \\
\hline 19 & 61 & $M$ & 12 & 18 & Lt. MCA & 77.1 & 13 & 8.55 & 9.6 & 7.4 & Anomic \\
\hline 20 & 78 & $\mathrm{~F}$ & 12 & 25 & Lt. ICH & 37.7 & 2 & 7.05 & 5.4 & 4.4 & Broca \\
\hline
\end{tabular}

$\mathrm{K}-\mathrm{WAB}=$ Korean version of Western Aphasia Battery (Kim \& Na, 2001); $A Q=$ aphasia quotient; $B G=$ basal ganglia; ICH=intracerebral hemorrhage; $M C A=$ middle cerebral artery; $S A H=$ subarachnoid hemorrhage; ICA=internal carotid artery.

Appendix 2. 정상 집단 정보

\begin{tabular}{rcccc}
\hline 번호 & 연령 & 성별 & 교육년수 & K-MMSE \\
\hline 1 & 71 & $\mathrm{M}$ & 12 & 29 \\
2 & 74 & $\mathrm{M}$ & 16 & 26 \\
3 & 69 & $\mathrm{M}$ & 16 & 29 \\
4 & 70 & $\mathrm{~F}$ & 9 & 28 \\
5 & 65 & $\mathrm{~F}$ & 12 & 30 \\
6 & 68 & $\mathrm{~F}$ & 9 & 30 \\
7 & 66 & $\mathrm{~F}$ & 9 & 26 \\
8 & 61 & $\mathrm{~F}$ & 14 & 30 \\
9 & 68 & $\mathrm{~F}$ & 9 & 28 \\
10 & 63 & $\mathrm{~F}$ & 12 & 27 \\
11 & 66 & $\mathrm{~F}$ & 10 & 30 \\
12 & 52 & $\mathrm{~F}$ & 18 & 30 \\
13 & 56 & $\mathrm{M}$ & 23 & 30 \\
14 & 58 & $\mathrm{~F}$ & 18 & 30 \\
15 & 36 & $\mathrm{M}$ & 16 & 30 \\
16 & 24 & $\mathrm{M}$ & 14 & 30 \\
17 & 28 & $\mathrm{M}$ & 16 & 29 \\
18 & 59 & $\mathrm{M}$ & 12 & 27 \\
19 & 48 & $\mathrm{M}$ & 12 & 29 \\
20 & 52 & $\mathrm{~F}$ & 12 & 30 \\
\hline $\mathrm{K}$ & & & & \\
\hline
\end{tabular}

K-MMSE=Korean version of Mini Mental State Examination (Kang, Na, \& Hahn, 1997). 
Appendix 3. 의미성 및 규칙성에 따른 읽기 자극 목록

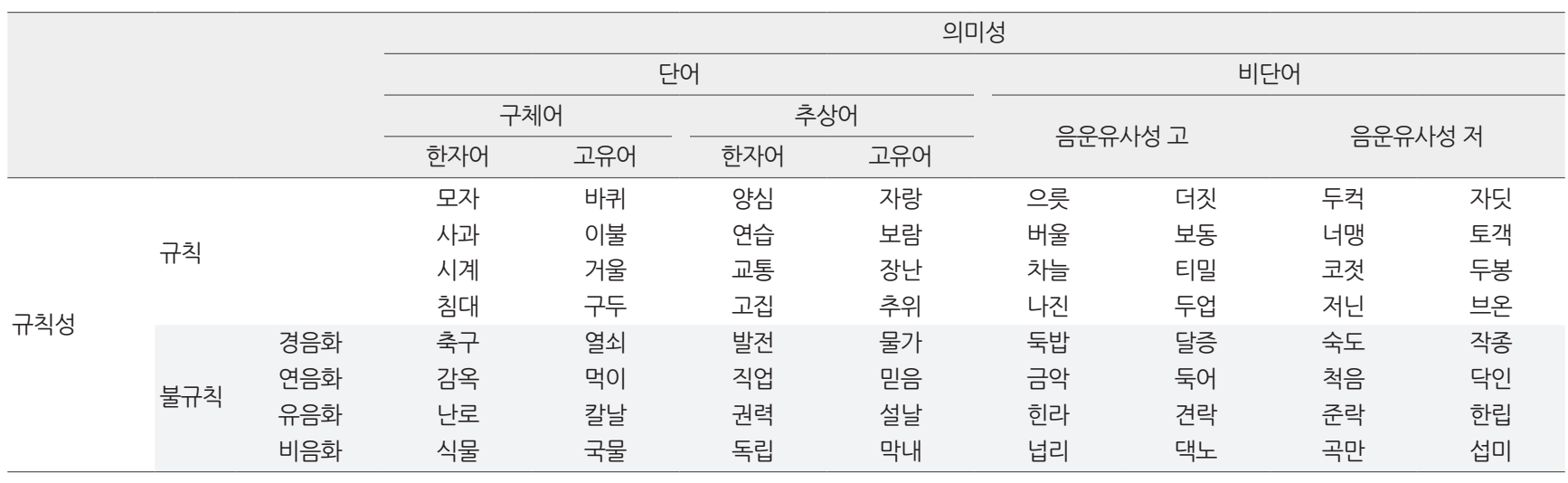

Appendix 4. 읽기 오류 유형 및 예시

\begin{tabular}{|c|c|c|c|}
\hline 조건 & 오류 양상 & 오류 유형 & 예시 \\
\hline \multirow{8}{*}{ 단어 } & \multirow{4}{*}{ 단어 $\rightarrow$ 단어 } & 시각 착어 & 거울 $\rightarrow$ 겨울 \\
\hline & & 의미 착어 & 이불 $\rightarrow$ 베개 \\
\hline & & 비관련 단어로 읽음 & 연습 $\longrightarrow$ 열매 \\
\hline & & 규칙화(음운변동 적용 안함) & 난로 $\longrightarrow$ 난/로 \\
\hline & 단어 $\rightarrow$ 비단어 & 음소 또는 음절을 대치하여 비단어로 읽음 & 추위 두위 \\
\hline & \multirow{3}{*}{ 기타 } & 신조어 & 축구 $\longrightarrow$ 토코 \\
\hline & & 무반응 & - \\
\hline & & 보속현상 & - \\
\hline \multirow{6}{*}{ 비단어 } & \multirow{2}{*}{ 비단어 $\rightarrow$ 비단어 } & 음소 또는 음절을 대치하여 비단어로 읽음 & 토객 $\rightarrow$ 토갱 \\
\hline & & 규칙화(음운변동 적용 안함) & 척음 척/음 \\
\hline & 비단어 $\rightarrow$ 단어 & 어휘화(비단어를 단어로 읽음) & 두컥 $\rightarrow$ 주걱 \\
\hline & \multirow{3}{*}{ 기타 } & 신조어 & 숙도 $\rightarrow$ 돌개 \\
\hline & & 무반응 & - \\
\hline & & 보속현상 & - \\
\hline
\end{tabular}




\section{국문초록}

\section{어휘 의미성 및 철자 규칙성에 따른 실어증 환자의 명사 소리내어 읽기 특징}

\section{김운정 · 성지은}

이화여자대학교 대학원 언어병리학과

배경 및 목적: 의미성 및 규칙성에 따른 읽기 과제에서 실어증 환자군과 정상군의 명사형 자극 읽기 수행률을 비교하고 그 특징을 살펴 보고자 한다. 방법: 실어증 환자 20 명과 정상 성인 20 명을 대상으로 하였으며, 의미성 및 규칙성에 따라 규칙 단어, 불규칙 단어, 규칙 비 단어, 불규칙 비단어 조건에서 2 음절 명사형 읽기 자극을 선정하였다. 대상자는 제시된 목표단어를 보고 소리내어 읽도록 지시하였으 며, 최종 반응을 전사하여 정반응률을 계산하고 오류 유형을 분석하였다. 결과: 의미성 및 규칙성에 따른 2음절 명사형 자극 읽기에서 실어증 환자군이 정상군에 비해 유의하게 낮은 정반응률을 보였다. 또한 의미성에 따른 집단 간 읽기 수행률의 차이가 유의하였다. 반 면 규칙성에 따른 집단 간 차이 및 규칙성 및 어휘성에 따른 집단 간 차이는 유의하지 않았다. 실어증 중증도를 예측하는 변인은 규칙 비 단어로, 약 $47.7 \%$ 의 예측력을 가지는 것으로 나타났다. 오류 비율은 비단어가 단어에 비해 2 배 이상 높았으며, 비단어 조건에서 더 많은 규칙화 오류가 나타났다. 논의 및 결론: 실어증 환자는 후천적인 뇌손상으로 인해 읽기 결함을 보이며, 빈도가 통제되었을 때 규칙성에 비해 의미성에 따른 영향을 더 크게 받는다. 즉 실어증 환자군은 전반적으로 단어에 비해 비단어의 읽기 수행력이 저조한 특징을 보이 며, 이는 음운성 실독증의 유형과 유사하다. 또한 철자-음소 전환 과정이 필요한 규칙 비단어가 실어증 중증도를 예측하는 변인이다.

핵심어: 실어증, 읽기, 의미성, 규칙성

본 연구는 2016년 대한민국 교육부와 한국연구재단의 지원을 받아수행된 연구임(NRF-2016S1A5B6913884).

\section{참고문헌}

강연욱, 나덕렬, 한승혜(1997). 치매환자들을 대상으로 한 K-MMSE의 타당도연구. 대한신경과학회지, 15, 300-308.

김민정, 이승복, 정범석(2009). 단어재인에 미치는 연상과 심상성의 영향. 인지과학, 20, 243-274.

김향희(2012). 신경언어장애. 서울: 시그마프레스.

김향희, 나덕렬(2001). 파라다이스-한국판-웨스턴실어증검사. 서울: 파라다이스 복지재단.

남기춘, 김재연, 서창원(2001). 한글 단어재인에서의 형태점화 효과. 한국심리학회지: 실험 및 인지, 13, 21-40.

남기춘, 서광준, 최기선, 이경인, 김태훈, 이만영(1997). 한글 단어 재인에서의 단어 길이 효과. 한국심리학회지: 실험 및 인지, 9, 1-18.

박권생(1993). 한글 단어 재인에 관여하는 정신 과정. 한국심리학회지: 실험 및 인지, 5, 40-55.

백여정(2004). 실독증 환자들의 한자어와 고유어 소리내어 읽기 비교. 연세대학교 석사학위논문.

이광오(1996). 한글 글자열의 음독과음운규칙. 한국심리학회지: 실험 및 인지, 8, 1-23.

이상억(1990). 현대국어음변화 규칙의 기능부담량. 한글 및 한국어정보처리 학술발표논문집, 131-138.

이상억(2001). 계량국어학 연구. 서울: 서울대학교출판부.

이창환, 김연희, 강봉경(2003). 한글 단어 재인에 있어서 음운정보와시각정보의 역할. 한국심리학회지: 실험, 15, 1-17.

이해숙, 김정오(2003). 음운 규칙의 적용 용이성이 음운 정보처리에 미치는 효과. 한국심리학회지: 실험, 15, 425-454.

이해숙(2003). 음운 규칙의 분류와 비단어자극의 적합성: 표면음운형과 기저음운형의 음성 실현 양상을 중심으로. 서울대학교 석사학위논문.

임유경(2006). 한글단어재인에서 음운규칙의 적용도 연구. 이화여자대학교대학원 석사학위논문.

정한글(2015). 노년층의 작업기억용량이 단어의 음운 유사성 및 듣기 조건에 따라 말지각 능력에 미치는 영향. 이화여자대학교 석사학위논문.

조경덕(2005). 실어증 환자의 난독증과 난서증에 관한 연구. 인문논총, 22, 161-179.

조경덕, 정재범, 남기춘(2002). 후천성 한글 난독증의 어휘처리 양상: 읽기, 명명, 쓰기 장애에 대한 사례연구를 중심으로. 언어청각장애연구, 7, 1-20.

조혜숙, 남기춘(2002). 실어증 환자에서 보이는 단어규칙성 효과. 언어청각장애연구, 7, 77-94.

조혜숙, 편성범(2015). 한국어 후천성 음운성 실독증의 특성. 언어청각장애연구, 20, 570-586.

태진이, 이창환, 이윤형(2015). 한국어 시각 단어재인과정에서 음운정보와 표기정보의 역할. 인지과학, 26, 1-26. 